\title{
3.3 Моделювання процесів роботи електромеханічного амортизатора та ефективність його застосування на рейковому міському транспорті
}

Безпека руху і ефективність використання рухомого складу міського електротранспорту залежить від його конструкції, особливо від систем, що забезпечують динамічні показники. Це, в першу чергу, відноситься до ходових частин та тягового електроприводу.

Невід’ємним елементом ходових частин візків вагонів є системи ресорного підвішування, що забезпечує надійність роботи рухомого складу, комфортність поїздки та безпеку руху. Їх робота пов'язана з гасінням коливань кузова від нерівності рейок та зовнішніх впливів.

Для гасіння коливань кузова застосовують різні конструкції амортизаторів (гасителів): гідравлічні, фрикційні, пневматичні. Але вони мають ряд недоліків. При використанні гідравлічних гасителів неможливе регулювання їх параметрів при різному навантаженні вагонів. Фрикційні гасителі мають нерівномірний знос їх частин під час експлуатації, внаслідок чого змінюється характеристика їх конструкції. Пневматичні гасителі коливань потребують додаткових витрат енергії та потужностей пневматичної системи вагонів. Гасителі коливань, що використовуються в своїй більшості витрачають енергію коливань на нагрівання, що $є$ не ефективним.

Перспективним $є$ використання електромеханічних амортизаторів, які можуть додаткового генерувати електричну енергію для внутрішніх потреб рухомого складу.

Вибір електромеханічного амортизатора заснований на типі, конструкції і тяговій (механічній) характеристиці лінійного електромеханічного перетворювача. Обираючи тип i конструкції такого перетворювача для електромеханічного амортизатору відзначимо, що він не підпадає ні під один 3 видів існуючої їх класифікації: силовий, енергетичний i потужний [208-210, 215]. 
Електромеханічний перетворювач для амортизатору знаходиться в рамках класифікації усіх типів перетворювачів одночасно.

Для електромагнітного перетворювача характерна досить нерівномірна характеристика залежності сили тяги від переміщення, яка близька до гіперболічної.

Для системи ресорного підвішування ходової частини візка по своїм характеристикам та параметрам регулювання струму підходить лінійний електромеханічний перетворювач, який має постійну тягову характеристику, яка змінюється лише від швидкості руху якоря [202].

Для визначення параметрів i характеристик електромеханічного амортизатору розглянемо його особливості конструкції та принцип дії (рис. 2.1).

Принцип дії амортизатора заснований на електромагнітних явищах. Постійний магніт 4 (див. мал. 1) має радіальне намагнічення. Силові магнітні лінії потоку збудження замикаються по колу: повітряний зазор 3 якорем 1 та обмоткою якорю 2, спинка станини та станина 3, постійний магніт 4. Потік збудження зчіплюється з обмоткою якоря і під дією зовнішніх динамічних сил, які виникають під час коливання кузова та візка, якір рухається (униз або вгору).

У обмотці якоря виникає ЕРС. При навантаженні на обмотку якоря виникає струм якоря. 


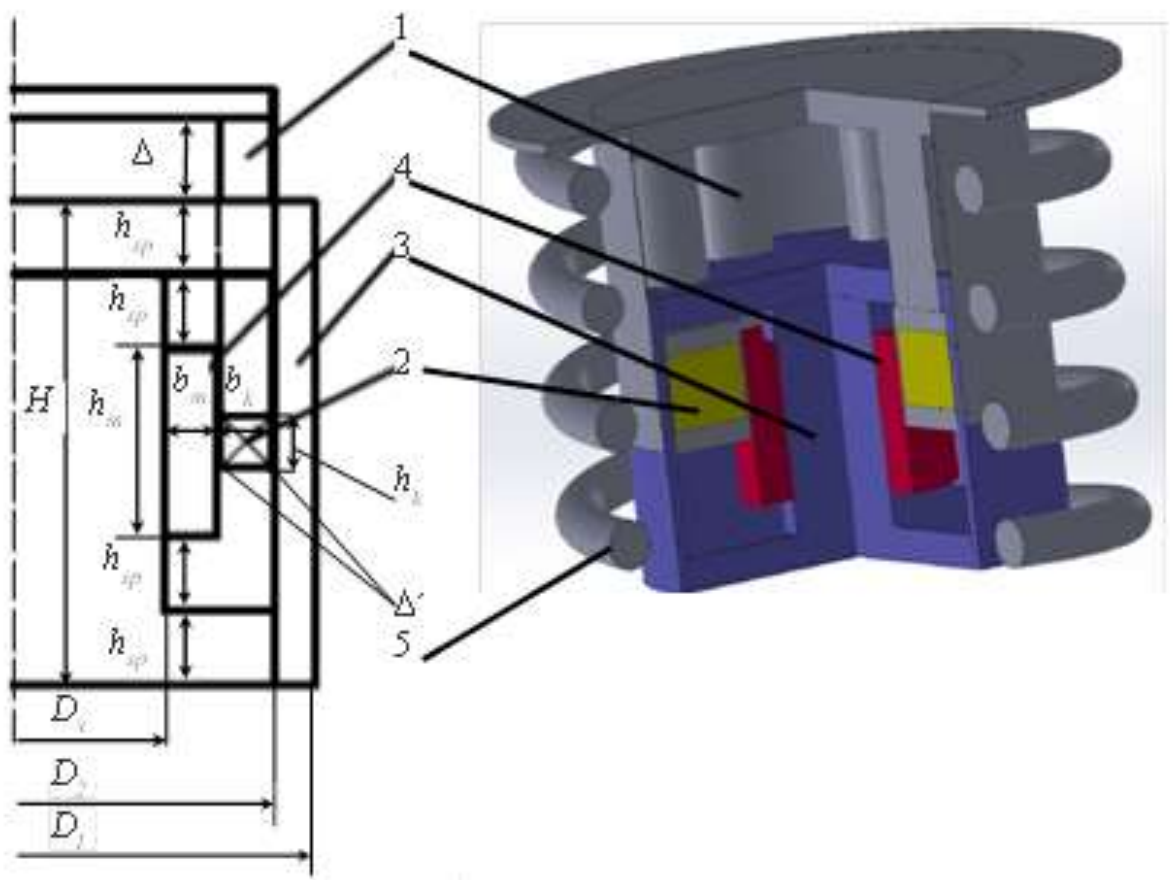

Малюнок 1. Електромеханічний амортизатор постійного струму:

1 - якір; 2 - обмотка якорю; 3 - станина; 4 - постійний магніт

Основні параметри характеристики електромеханічного амортизатору наведені у таблиці 1 згідно малюнку 1. Вони обрані евристично та приблизно відповідають вимогам щодо амортизатору вагону метрополітену.

Електромагнітну силу, що діє на обмотку якоря з магніторушійною силою (МРC) $F=i w$ та електрорушійну силу (ЕРC), можливо обчислити за виразом [218]:

$$
\begin{aligned}
& F_{d e m}=B_{\delta}(i w) l_{s r}, \\
& E_{d e m}=B_{\delta} V_{d e m} l_{s r} .
\end{aligned}
$$

де $B_{\delta}$-індукція магнітного поля у повітряному зазорі $\delta$;

$l_{s r}-$ середня довжина вітка, яку можливо обчислити з геометричних параметрів амортизатору за виразом:

$$
l_{s r}=\pi\left(D_{3}+2 b_{m}+2 \Delta^{\prime}+b_{k}\right),
$$


де $V_{d e m}-$ номінальна швидкість якоря амортизатора.

У останній час в якості матеріалів для постійних магнітів використовуються сплави $\mathrm{NdFeB}$. Вони мають приблизно лінійну криву розмагнічення (мал. 2).

Основний опір магнітному потоку $є$ повітряний зазор між постійним магнітом та станиною. Він складається 3 товщини обмотки та двох технологічних зазорів $\left(b_{k}+2 \Delta^{\prime}\right)$.

Таблиця 1.

Основні характеристики електромеханічного дослідного амортизатору

\begin{tabular}{|l|l|l|}
\hline Параметр & \multicolumn{1}{|c|}{ Величина } & \multicolumn{1}{|c|}{ Примітки } \\
\hline$F_{d e m}$ & $2000 \mathrm{H}$ & $\begin{array}{l}\text { Номінальна електромагнітна сила на якорі } \\
\text { амортизатора }\end{array}$ \\
\hline$V_{d e m}$ & $0,08 \mathrm{M} / \mathrm{c}$ & Номінальна швидкість якоря амортизатора \\
\hline$\Delta$ & $0,08 \mathrm{м}$ & $\begin{array}{l}\text { Максимальний хід амортизатора, згідно } \\
\text { рисунку 2.1 }\end{array}$ \\
\hline$H_{c}$ & $9,510^{5} \mathrm{~A} / \mathrm{M}$ & Коерцитивна сила постійного магніту \\
\hline$B_{o s t}$ & $1,05 \mathrm{Tл}$ & Остаточна індукція постійного магніту \\
\hline$I_{W}$ & $5120 \mathrm{~A}$ & МРС обмотки якоря у номінальному режимі \\
\hline$h$ & $0,293 \mathrm{м}$ & Висота ярма амортизатора, згідно малюнку 1 \\
\hline$D_{1}$ & $0,360 \mathrm{м}$ & $\begin{array}{l}\text { Зовнішній діаметр амортизатора, згідно } \\
\text { малюнку 1 }\end{array}$ \\
\hline$D_{2}$ & $0,312 \mathrm{м}$ & Згідно малюнку 1 \\
\hline$D_{3}$ & $0,18 \mathrm{м}$ & Згідно малюнку 1 \\
\hline$h_{m}$ & $0,114 \mathrm{м}$ & Висота постійного магніту, згідно малюнку 1 \\
\hline$b_{m}$ & $0,032 \mathrm{м}$ & Товщина постійного магніту, згідно малюнку 1 \\
\hline$h_{k}$ & $0,034 \mathrm{м}$ & Висота обмотки якоря, згідно малюнку 1 \\
\hline$b_{k}$ & $0,0325 \mathrm{м}$ & Товщина обмотки якоря, згідно малюнку 1 \\
\hline$h_{s p}$ & $0,045 \mathrm{м}$ & Товщина спинки якоря, згідно малюнку 1 \\
\hline$\Delta^{\prime}$ & $0,001 \mathrm{м}$ & Технологічні повітряні зазори, згідно малюнку 1 \\
\hline
\end{tabular}

Для розрахунку параметрів приймаються наступні припущення: 
- опір магнітному потоку складається з опору повітряного зазору,

- незначність впливу потоку струму обмотки якоря на режим роботи постійного магніту,

- визначення індукції у постійному магніті, яка дорівнює індукції у повітряному зазорі можливо за геометричними відношеннями з малюнку 2.

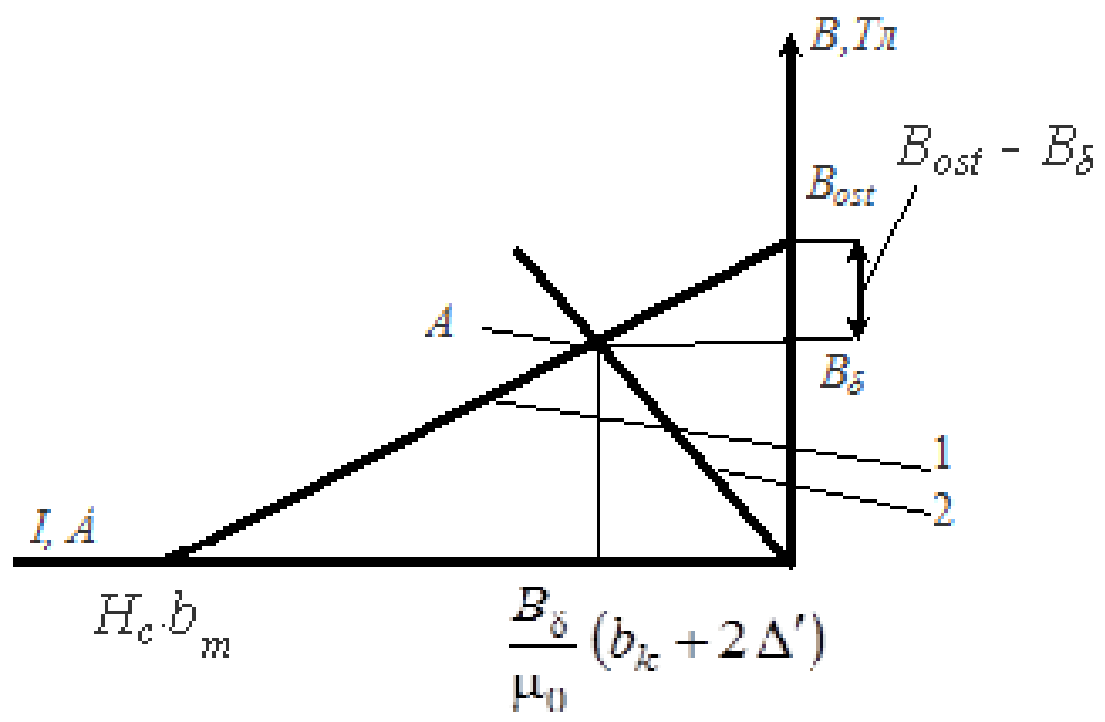

Малюнок 2. До визначення індукції магнітного поля у повітряному зазорі:

1 - магнітна характеристики постійного магніту;

2 - магнітна характеристика повітряного зазору.

Магніторушійна сила у робочий точці А визначається виразом:

$$
\frac{B_{o s t}-B_{\delta}}{B_{o s t}}=\frac{\frac{B_{\delta}}{\mu_{0}}\left(b_{k}+2 \Delta^{\prime}\right)}{H_{c} b_{m}} .
$$

3 виразу (3) отримаємо:

$$
B_{\delta}=\frac{1}{\frac{1}{B_{o s t}}+\frac{\left(b_{k}+2 \Delta^{\prime}\right)}{\mu_{0} H_{c} b_{m}}} .
$$

Підставивши вирази (2) та (4) у (1) отримаємо: 


$$
\begin{aligned}
F_{\text {dem }}= & \pi \frac{D_{3}+2 b_{m}+2 \Delta^{\prime}+b_{k}}{\frac{1}{B_{o s t}}+\frac{\left(b_{k}+2 \Delta^{\prime}\right)}{\mu_{0} H_{c} b_{m}}} I W, \\
E_{d e m} & =\pi \frac{D_{3}+2 b_{m}+2 \Delta^{\prime}+b_{k}}{\frac{1}{B_{\text {ost }}}+\frac{\left(b_{k}+2 \Delta^{\prime}\right)}{\mu_{0} H_{c} b_{m}}} V_{d e m} .
\end{aligned}
$$

Вираз (5) $є$ спрощена математична модель щодо визначення електромагнітної сили та ЕРС електромеханічного амортизатору.

При створенні моделі прийнято допущення - запасена електромагнітна енергія, яка використовується для опису машини, розглядається лише як енергія поля нульового порядку, тобто енергія статичного магнітного поля. Енергія електростатичного поля сконцентрована лише в конденсаторі.

Розробка динамічної моделі заснована на узагальненій схемі [201, 219], яка має у центральному ступені ресорного підвішування пружини і паралельно ним встановлені гідравлічні гасителі, а також пневматичні ресори. Для рішення задачі обрана розробка просторової кінематичної схеми динамічної системи екіпаж-колія для метровагону з осьовою формулою 20-20.

При цьому параметри буксового ступеня не змінювалися і були прийняті відповідно до результатів, отриманих в [219]. Виходячи з них відзначено, що модель створення рейкового шляху має спрощений вигляд і представлена як дискретна модель, відповідно якої до кожного колеса колісної пари приведена зосереджена маса шляху, пружина і гідравлічний гаситель. Такий підхід найбільш прийнятний для дослідження характеристик електромеханічного амортизатору. 3 урахуванням змін у подібної схемі розроблена узагальнена механічна модель центрального ступеня ресорного підвішування вагону метрополітену.

Для визначення положень математичної моделі обрані наступні узагальнені енергетичні параметри амортизатору: узагальнена координата $q_{k}$, узагальнена швидкість $q_{k}^{\prime}$, узагальнений імпульс сили $p_{k}$, узагальнена сила $f_{k}$. Для механічної системи взагалі не виникає сумнівів, що розуміти під 
координатою, швидкістю, силою або імпульсом. Інша ж ситуація виникає при виборі електричних координат.

Збережена електрична енергія електромеханічної системи складається 3 потенційної енергії і кінетичної коенергіi. Це означає, що якщо визначити заряд $q$ як узагальнену координату $q_{k}$, то збережена електрична енергія буде визначена як потенційна.

Представимо амортизатор у вигляді системи, що має одну електричну $q_{1}$ та одну механічну координату $q_{2}$. (мал. 3). 3 урахуванням комплексу попередніх досліджень для підвищення швидкодії амортизатору в електричне коло включено конденсатор $C$. Створене, таким чином електричне коло $L-R$ - $C$ уявляє собою резонансний контур, який настроєно на частоту власних коливань кузова вагону метрополітену.

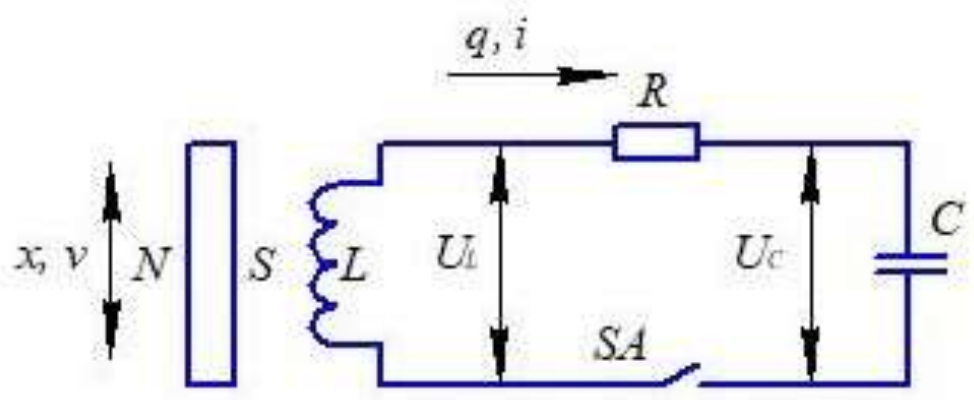

Малюнок 3. Електромеханічна схема амортизатору

Якщо розглядати дію неконсервативної сили $Q_{k}$ по $k$-ой координаті $q_{k}$ спільно з консервативними силами системи, то згідно з принципом Даламбера при динамічній рівновазі сума всіх сил, включаючи не консервативні, повинна дорівнювати нулю. Тому рівняння Лагранжа має такий вигляд [205]:

$$
\frac{\partial L}{\partial q_{k}}-\frac{d}{d t}\left(\frac{\partial L}{\partial \dot{q}_{k}}\right)-\left(\frac{\partial F}{\partial \dot{q}_{k}}\right)+Q_{k}=0,
$$

де $\boldsymbol{L}$ - силова функція Лагранжа, $F$ - релеєва функція, яка враховує втрати в системі. 
Після визначення узагальнених координат вибираємо силову функцію Лагранжа або лагранжіан, $L(q, \dot{q}, t)$, який будемо використовувати для отримання рівнянь руху. Лагранжіан визначається як різниця між кінетичною коенергіей $T$ і потенційною енергією $V$, тобто

$$
L=T-V \text {. }
$$

Основні складові рівняння (6) наведено у таблиці 2.

Таблиця 2.

Узагальнені електромеханічні параметри електромеханічного амортизатору

\begin{tabular}{|l|l|}
\hline \multicolumn{1}{|c|}{ Узагальнений параметр } & \multicolumn{1}{|c|}{ Фізичний параметр } \\
\hline$q_{1}$ - координата 1 & $q$ - заряд \\
\hline$q_{2}$ - координата 2 & $x$ - переміщення якоря \\
\hline$q_{1}^{\prime}$ - швидкість 1 & $i$ - струм в обмотці \\
\hline$q_{2}^{\prime}$ - швидкість 2 & $V$ - швидкість якоря \\
\hline$Q_{1}$ - зовнішня сила 1 & 0 \\
\hline$Q_{2}$ - зовнішня сила 2 & $F$ - сила, що прикладена до якоря \\
\hline
\end{tabular}

Через узагальнені змінні визначені параметри для кінетичної коенергіi i потенційної енергії консервативної частини системи за наступними рівняннями:

- кінетична коенергія:

$$
T=\int_{0, \ldots, 0}^{q 1, \ldots, q M} \sum_{k=1}^{M+1} p_{k}\left(q_{1}, \ldots, q_{M+1} ; \dot{q}_{1}, \ldots, \dot{q}_{M+1} ; t\right) d \dot{q}_{k}
$$

- потенційна енергія

$$
V=\int_{0, \ldots, 0}^{q_{1}, \ldots, q M} \sum_{k=1}^{M+1}-f_{k}\left(q_{1}, \ldots, q_{M+1} ; t\right) d q_{k} .
$$

3 урахуванням (6), (8) та (9) отримано вирази для коенергії і потенційної енергії консервативної частини системи:

$$
T=\frac{1}{2} \cdot M v^{2}+\int_{0}^{i} \Psi(i, x) d i,
$$




$$
V=-\frac{1}{2} k\left(x+x_{n}\right)^{2}-\frac{1}{2} C q^{2}
$$

Консервативний лагранжіан по (6) дорівнює:

$$
L=\frac{1}{2} \cdot M v^{2}+\int_{0}^{i} \Psi(i, x) d i,-\frac{1}{2} k\left(x+x_{n}\right)^{2}-\frac{1}{2} C q^{2}
$$

Релеєва функція втрат:

$$
F=\frac{1}{2}\left(R i^{2}+\alpha v^{2}\right)
$$

де $\quad \alpha-$ коефіцієнт механічного демпфування.

Підставляючи (10)-(13) в (6) і з урахуванням похідних:

$$
\begin{gathered}
\frac{\partial L}{\partial q_{1}}=\frac{\partial L}{\partial q}=-C q \\
\frac{\partial L}{\partial q_{2}}=\frac{\partial L}{\partial x}=\frac{\int_{0}^{i} \Psi(i, x) d i}{\partial x}-k\left(x+x_{n}\right), \\
\frac{\partial L}{\partial \dot{q}_{1}}=\frac{\partial L}{\partial i}=\Psi(i x) \\
\frac{\partial L}{\partial \dot{q}_{2}}=\frac{\partial L}{\partial v}=M v \\
\frac{\partial F}{\partial \dot{q}_{1}}=\frac{\partial F}{\partial i}=R i \\
\frac{\partial F}{\partial \dot{q}_{2}}=\frac{\partial F}{\partial v}=\alpha v
\end{gathered}
$$

отримаємо для електричних координат рівняння виду:

$$
-C q-\frac{d}{d t}(\Psi(i, x))-R i=0
$$




$$
\frac{\int_{0}^{i} \Psi(i, x) d i}{\partial x}-k\left(x+x_{n}\right)-\frac{d}{d t}(M v)-\alpha v+F_{g}=0 .
$$

Вираз $\frac{\int_{0}^{i} \Psi(i, x) d i}{\partial x}=F_{e}$ визначає електромагнітну силу, яку створює амортизатор.

Оскільки потокозчеплення $\Psi$ - це складна функція, яка залежить від всіх координат, то загальну похідну $\frac{d \Psi}{d t}$ можна уявити в такому вигляді:

$$
\frac{d \Psi}{d t}=\frac{\partial \Psi}{\partial i} \cdot \frac{d i}{d t}+\frac{\partial \Psi}{\partial x} \cdot \frac{d x}{d t} .
$$

Ураховуючи, що $U_{c}=-C q$, рівняння (20) має вигляд:

$$
U_{c}-\frac{\partial \Psi}{\partial i} \cdot \frac{d i}{d t}-\frac{\partial \Psi}{\partial x} \cdot \frac{d x}{d t}-R i=0
$$

Вирази $\frac{\partial \Psi}{\partial i}=L$ та $\frac{\partial \Psi}{\partial x}=K$ визначають диференціальну індуктивність та коефіцієнт при протиЕРС [203], які можливо ідентифікувати за результатами розрахунків магнітного поля.

Загалом вираз (23) можливо представити у вигляді:

$$
\left\{\begin{array}{l}
\frac{d i}{d t}=\frac{U_{c}-i \cdot R-K \cdot v}{L}, \\
\frac{d U_{c}}{d t}=-\frac{i}{C} .
\end{array}\right.
$$

Враховуючи, що $F_{g}=M g$, де $g$ - прискорення вільного падіння, а $M-$ приведенні маса кузова, вираз (3.16) можливо перетворити до вигляду

$$
\frac{d v}{d t}=\frac{F_{e}-m g-k\left(x+x_{n}\right)-\alpha v}{M}
$$


Додавши до (24) та (25) рівняння зв'язку $\frac{d x}{d t}=v$ отримаємо узагальнену математичну модель електромеханічного амортизатору у вигляді задачі Коши.

$$
\left\{\begin{array}{l}
\frac{d i}{d t}=\frac{U_{c}-i \cdot R-K \cdot v}{L}, \\
\frac{d U_{c}}{d t}=-\frac{i}{C} \\
\frac{d v}{d t}=\frac{F_{e}-m g-k\left(x+x_{n}\right)-\alpha v}{M}, \\
\frac{d x}{d t}=v .
\end{array}\right.
$$

Математична модель (26) має вигляд, який сприйнятливий для використання при моделюванні процесів роботи електромеханічного амортизатору, але для іï використання необхідно ідентифікувати параметри моделі - диференціальну індуктивність та коефіцієнт при протиЕРС.

Результати моделювання показано на малюнках 4-7.

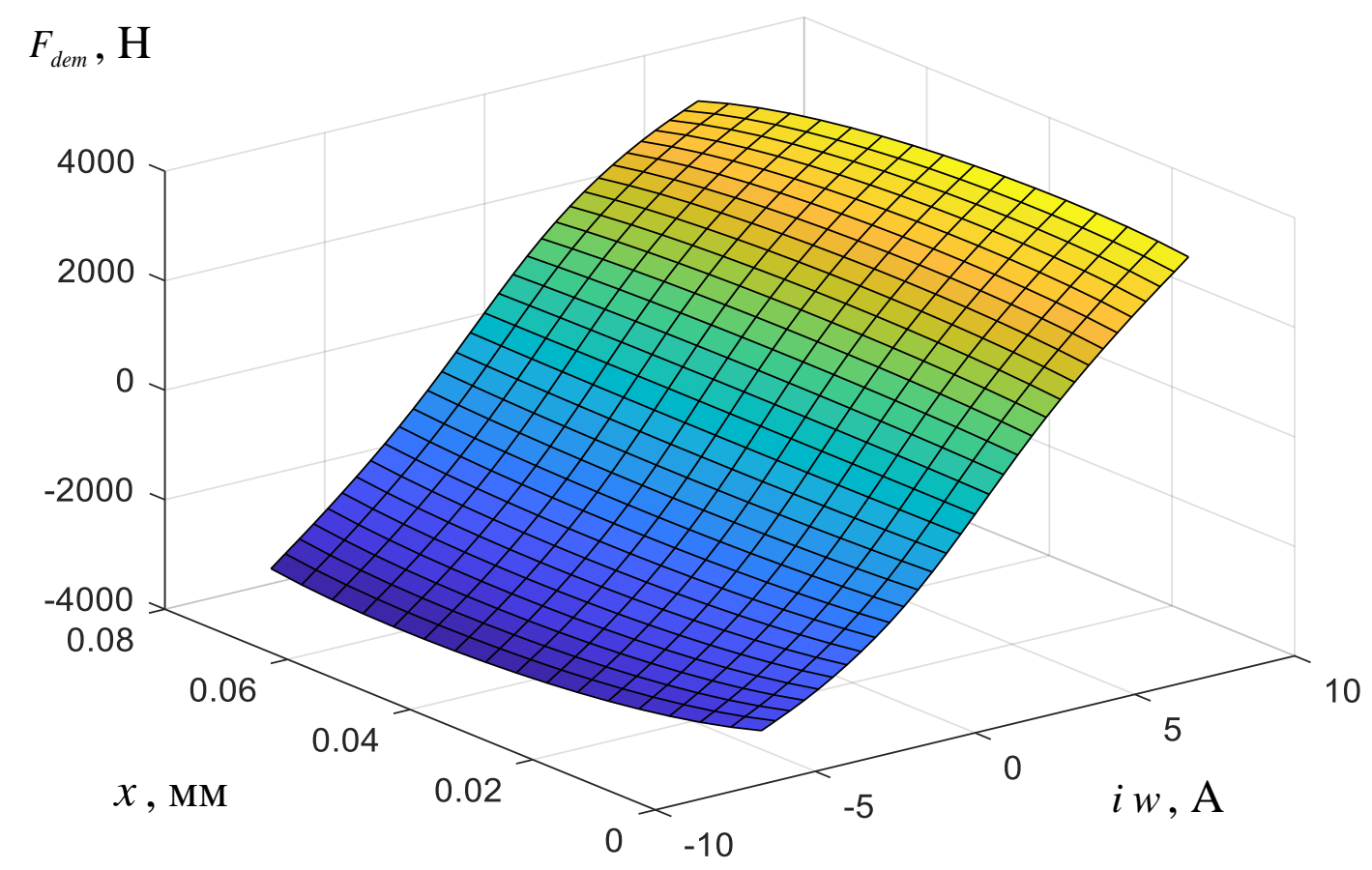

Малюнок 4. Залежність електромагнітної сили від переміщення та струму обмотки 


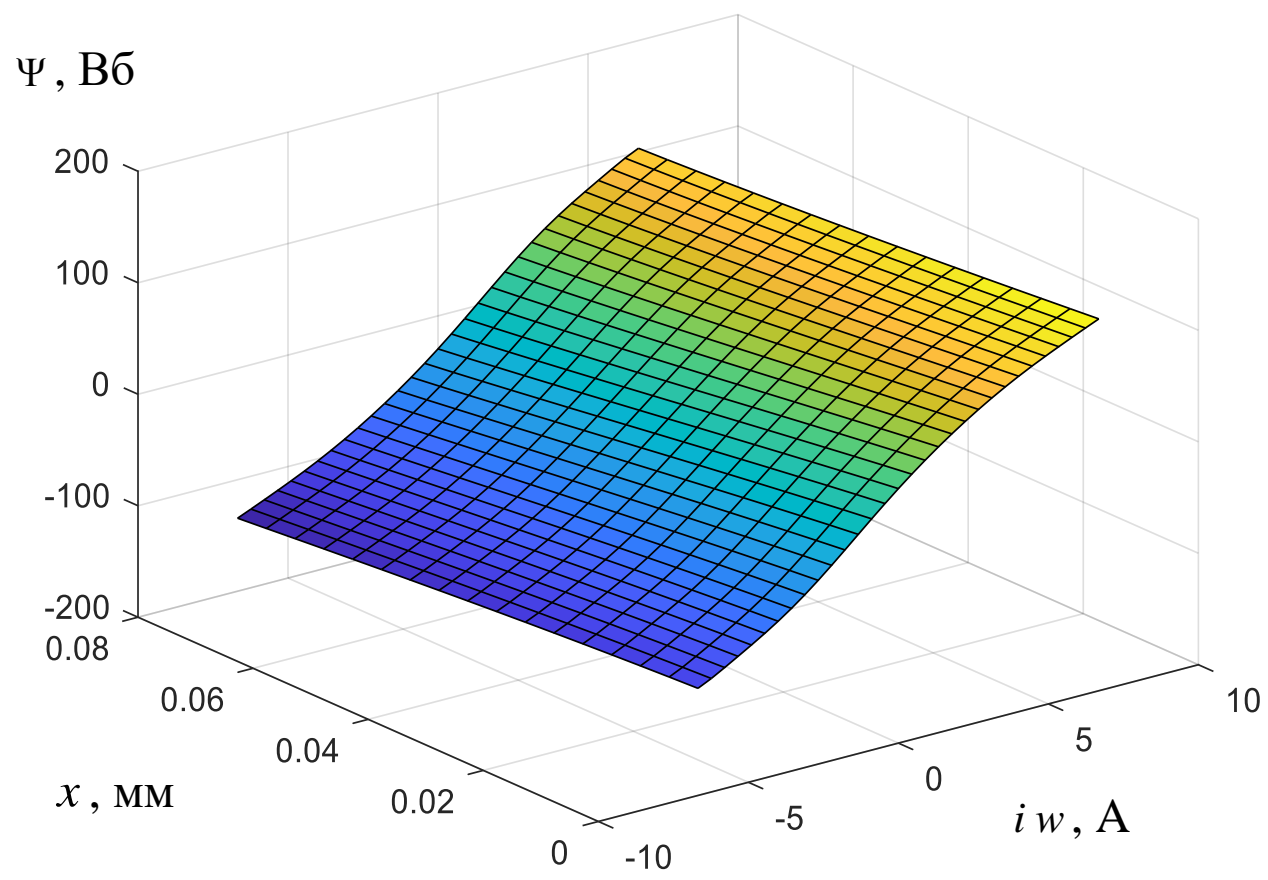

Малюнок 5. Залежність потокозчеплення котушки якоря від переміщення та струму обмотки

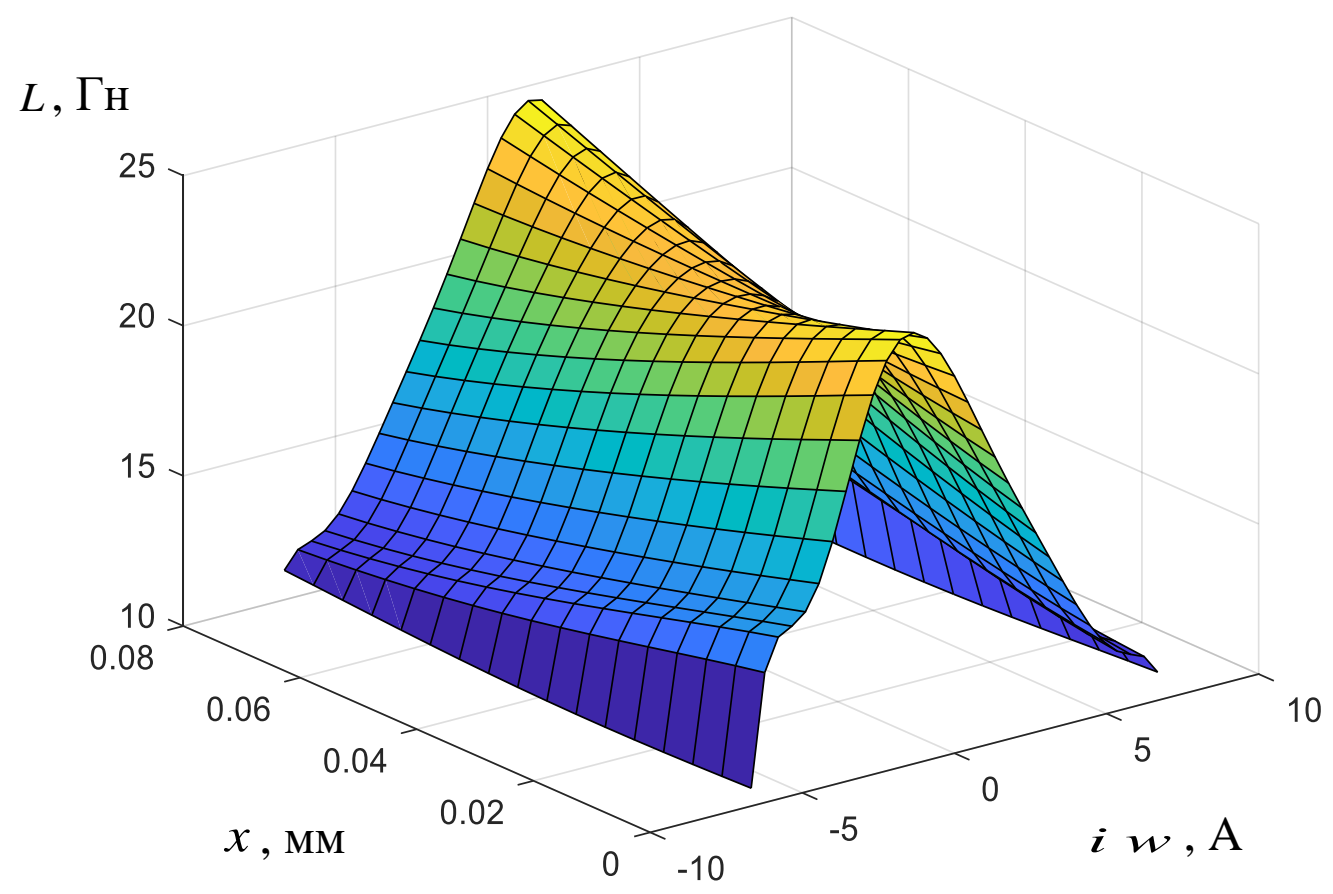

Малюнок 6. Залежність диференційної індуктивності від переміщення та струму обмотки 


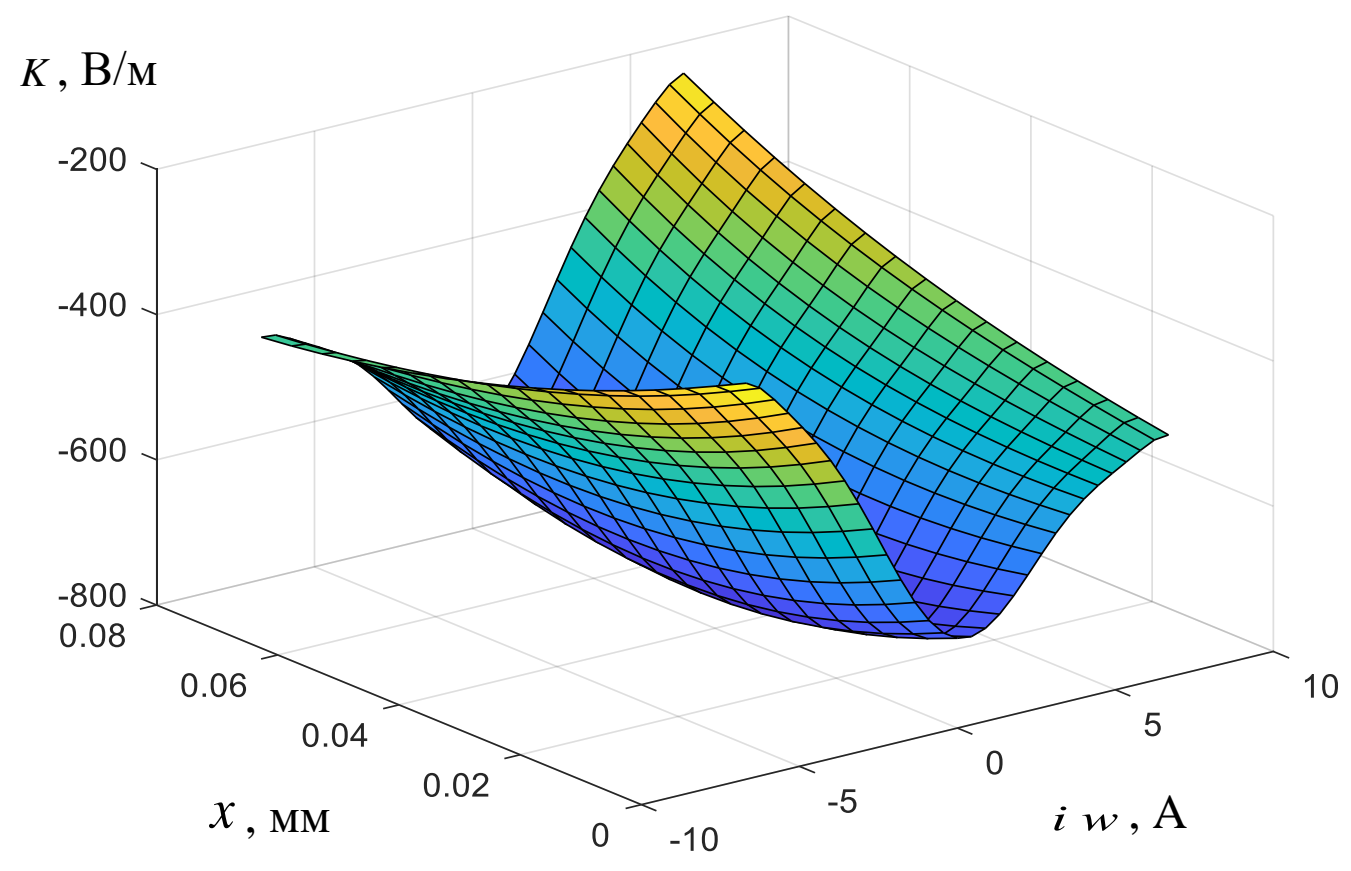

Малюнок 7. Залежність коефіцієнту при протиЕРС від переміщення та струму обмотки

Таким чином, за результатами розрахунку магнітного поля і подальшого регресійного аналізу отримано поліноміальні залежності похідних потокозчеплення по струму i лінійному переміщенню якоря, які дають можливість ідентифікувати узагальнену математичну модель електромеханічного амортизатора.

У роботі проведено аналіз умов роботи та конструкцій ходових частин рейкового транспорту; розроблено методи визначення оптимальних параметрів електромеханічного амортизатора для вагону метрополітену; проведено математичне моделювання електромеханічного амортизатора з урахуванням нестаціонарних процесів. 